\title{
WATER FOUNTAINS IN THE ISLAMIC ARCHITECTURE: SIMPLICITY OF TECHNIQUES \& FASCINATING PERFORMANCE
}

Mohamed Mohi eldin MAHMOUD *

Industrial Design Department, College of Applied Arts, Beni Suef University, Egypt

\begin{abstract}
Man, with his natural instinct, his delicate sense of beauty and his love for creativity, has tried to mold everything that his hands make into an artistic form, expressing his latent desires that vary according to his ability to innovate and the extent of his influence with what is around him. And he has always worked hard in adapting the nature around him to suit his physical and spiritual needs. Since ancient times, water has been an important and fundamental factor in the emergence, continuation and progress of most civilizations. Man has sought by his strong will and beneficial connection with water to employ the objective elements and conditions to create new forms and architectural structural elements to contain the element of water, which led, by extension, to the emergence of what is known as water fountains or water fountains. Fountains or fountains mean the process of moving water vertically upward, descending, or gradually, and in some cases complex water formations in which the philosophical aspects and which were inspired by environmental elements, climatic conditions, as well as the craftsmanship with it. Thanks to the genius and skill of Muslims in the science of mechanics and engineering sciences in creating many designs and shapes for water fountains, which depend on some simple mechanical parts and relationships, which led to their increasing spread and expansion by using them as a functional decorative element in various aspects. Life from mosques to homes, through squares, galleries and orchards. The problem lies in the presence of some trumpets that adopt the view that Muslims, despite their superiority in the knowledge of mechanics, have only used it for purposes limited to lavishness or luxury without having any beneficial or practical benefit.

Keywords

Water Fountains, The Islamic Architecture, Simplicity, Techniques, Fascinating Performance.
\end{abstract}

\section{Introduction}

Usually beauty and tranquility are associated with nature around us, so man has been keen to reconfigure vocabulary of nature in an effort to introduce it into homes and public gardens to add more beauty. And water fountains were "water fountains" one of the most important elements that people used for this purpose.

Water fountains can be defined as "a room or reservoir that contains a quantity of water or any other liquid that can be leaked in a certain way or in a specific way when needed", or as "a formation or structure that is usually decorative or aesthetic and from which a flow emerges. Or a stream of water, or it is a "stream or stream of water or any other liquid that is made by mechanical means that can be raised or raised through a hole or formation in order to supply water for use, to coat the temperature of the air or for the purpose of cosmetic and decoration." Also, sparkling water can be defined as "a decorative or aesthetic formation that throws streams of water into the air".

As for the more general definition, it is "a flow of water resulting from its pressure through narrow holes in a basin, which rises to a certain level first and then falls. This rise may occur

*Corresponding author: moheyeldin_mohamed@apparts.bsu.edu.eg 
either natural or artificial. The necessary pressure is generated for this by weighing the collected water in A reservoir and its temperature or both, as the water passes through underground channels until it can exit in the form of a spring or a fountain.

And the invention of the fountain is attributed to Heron of Alexandria, who lived in the second century $\mathrm{BC}$, even if there were some indications that point to the construction of the gardens of Babylon attached to the idea of pumping water to the heights, and there are some other indications that indicate the use of the Persians And the Romans for the water fountains in decorating gardens and entrances to palaces, since the year $4000 \mathrm{BC}$.

The Arabs began to transfer the books of the former, such as Euclid, Archimedes, Apollinus, Aristotle and Heron of Alexandria, and then appeared from them Muslim scientists and engineers who specialized in several sciences who developed them and set new scientific rules for them and devised pioneering applications to benefit from them. These sciences are the science of mechanics, or as it was known by the Arabs as the science of "tricks".

The science of tricks means "obtaining a great act from a little effort, that is, Muslims wanted it to benefit the human being and to use trickery in place of strength and the mind in place of muscles and God in place of the body in a clear and explicit application of the teachings and directives of Islam. For the forced labor system to spend their living matters that need a great physical effort, when Islam came, it prohibited forced labor and forbade the exhaustion of servants and slaves and burdening them beyond what the average person can afford, as well as forbidding hardship on animals, so Muslims tended to develop machines to do hard work.

The purpose of the previous ones of this knowledge was limited to the religious and spiritual influence of following their doctrines, such as the use of moving or speaking statues by priests, the use of musical organs and other instruments in the temples, and other things that Islam forbade and make the connection between a slave and his Lord Without mediation or a means of perceptual or visual deception.

The book "The Tricks" by Banu Musa bin Shakir, authored in Baghdad in the mid-ninth century $\mathrm{AD}$, is one of the most prominent evidence of the extent of this science's development in the Islamic world. And with the fact that these are brothers

The three had taken the works of Philon and Heron to be their area, but their work showed superior skill and great control over the physical fields, compared to the work of their predecessor the Greeks.

Those working in the history of science have limited the contributions of these brothers to the sciences that they have researched, and found that they are thanks to the development of many theories, among which is the theory of water height, which is still used today in the work of 
fountains, the invention of a mechanical structure that allows the vessels to fill themselves. Whenever it is empty, the invention of a fine copper watch, the invention of lamps in which the wicks rise automatically and the oil is poured into it automatically and the wind cannot extinguish it, as well as many self-moving musical instruments and water fountains whose sparkling waters rush in the form of different shapes and contrasting images.

The scientist and engineer Badi 'al-Zaman Abu al-Ezz bin Ismail, nicknamed al-Jazari, who died in $1114 \mathrm{CE}$, is considered the sheikh of Muslim scholars in the science of tricks, as he composed a writing called "the combination of science and work," which is what is called in Europe "engineering tricks" and it is from The most accurate books are described, explained, in detail, and localized with colored plates containing a description of his machines and inventions, as this book contains a description and design of about fifty mechanical machines in six different classifications, including the design of the two-cylinder pump (the suction pump), the invention of the crankshaft. Shaft, the invention of some mechanical watches that work with water and weights, as well as many fountains and water-lifting machines. The sohir historian George Sarton was described as the technical pinnacle of Muslims. There are still a few original copies of this book preserved in the museums of Europe, which they use as precious archaeological pearls.

The Banu Musa presented a recipe for five fountains that change the shape of their drainage at intervals, as they consisted of a large fountain in the middle surrounded by two smaller fizzy so that if the water escaped from the large fountain in the form of a gear, it would evaporate from the two smaller fountains in the form of a stream (rod) and vice versa.

As for Al-Jazari, he provided a description of six fountains, all of which are reciprocating machines, where water springs out for a short period of time, and then in the form of a spray before returning to its original form.

The Muslim engineer worked to give the water structure a cosmic symbol, where water represented for him the origin of life and that for the Almighty saying, "We made from water every living thing", in addition to the fact that water in itself symbolizes purity, purity and serenity. And the process of transferring water from its various sources to stone formations of ponds, basins and fountains in various forms to achieve environmental and aesthetic goals represented engineering miracles in and of themselves.

The Muslim engineer has made a good use of the water element in various models of gardens, mosques, palaces, squares ... etc., while he relied on some symbolic connotations in his design of the different shapes of fountains, as we find that the predominant form of fountains was a square in a symbolic reference to the surrounding land. The interior is often in the form of an 
octagon in a symbolic reference to paradise, as well as in reference to the bearers of the throne of the Most Gracious for the Almighty saying: "And he carries the throne of your Lord over them on the day eight." The triangular corners formed at the corners of the square are hollow or concave from the inside in the form of a half-circle, This makes the shape of the fountain or the basin appear as if its dome was placed over muqarnas in a symbolic reference to the dome of the sky.

The reasons for using water fountains in the Islamic state have varied and varied, some of which have been used to moisturize and moderate the temperature, and some that have been used as water surfaces and ponds containing some colored fish or birds, and thus the continuous flow of water helps to keep them clean and not Its stagnation, and some of which have been exploited by the continuous flow of water to prevent the surface of the still water from forming a reflective mirror reflecting the image around it. Also, water fountains were used for irrigation purposes, both for humans and livestock, as well as for irrigation purposes. Water fountains also had other uses, as they were used to create a kind of natural music that chimes with the surroundings in an amazing rhythm and a very sweet symphony.

Will Durant noted in his description, "The houses of the poor were then as they are now rectangular buildings standing up from mud adhered to mud, with a roof of a mixture of mud, plant sticks, tree branches, palm sap and straw. This type includes an open inner courtyard with a fountain and a tree at times, and it sometimes contained a range of wooden pillars, and a roofed portico between the courtyard and the rooms.

In a study conducted in Fez, Kingdom of Morocco, it was found that there are about 400 fountains inside mosques, dwellings, and antique schools, and the study also indicates the presence of these fountains in the city since the sixteenth century AD.

The water fountains in Al Hamra Palace and the Generalife's Paradise represent a sophisticated example of what the innovations of Muslims reached at that time.

The fountain in the middle of the Lions Square in particular is considered the best evidence of the extent of the genius of the Arab Muslim engineer in that period, as it was not only a fountain, but it is a high-precision water watch as well.

This fountain was established during the reign of Sultan Muhammad V in the form of a huge and round basin made of alabaster with a diameter of about three and a half meters while its depth is about $65 \mathrm{~cm}$, carried over the shoulders of twelve lions with a height of about $2 \mathrm{~cm}$, each lined up in a circular shape to throw The water from its mouths is poured into four intersecting channels through which the water flows, two of which end in two small marble fountains inside the two halls located in the north and south of the courtyard, while the other 
two channels, which are the shortest, end with two marble fountains next to the Sabaa Fountain or the original fountain. From 12 houses praising the Sultan and describing the fountain and the palace. As for the water clock in the fountain, the water was coming out from the mouth of one of the lions when the one hour came, while the water came out from the mouth of two lions when the second hour came, but if the twelve o'clock came, the water came out from the mouth of the twelve lions at once.

The water outlets in that fountain were disrupted for several years, after the fall of Andalusia when the Spanish tried to know its system and spoiled it, until a committee of European and United States scientists in the fields of physics, mechanics, engineering and some other disciplines came to discover that the water flowing inside the streams The fountain carries metal materials, these materials, especially lime, have accumulated inside the sewers and obstructed the flow of water, which led to the fountain stop working.

A comprehensive restoration of the fountain, which lasted 4 years, was carried out in which more than two hundred experts in various fields and from several institutions took part and cost millions of dollars, during which waterways were extended against oxidation to the mouth of the lion through the left foot of each of the twelve lions. , So that it is possible to precisely control the temperature and the quality of the water, as well as the degree of pressure of the flow of water from the mouths of the lions in addition to the degree of pressure of the water in the fountain on the dish that the black carries, which has an empty weight of more than two tons, while its weight exceeds three tons. When the water is flowing.

\section{Results:}

1-The craftsmanship and ingenuity of Muslims with the science of mechanics contributed to the creation of many applications that led to the widespread use of water fountains and the multiplicity of their functions in light of the harsh desert environment of the Islamic State and the difficulty of accessing water sources.

2-What the Muslims left and whose effects are still present to our time is the most telling evidence of the extent of the development of mechanics and its multiple applications, in which the field of architecture is the broadest field for those applications in the various eras of Islam. 3-The deficiency of some studies that adopted the opinion that Arabs and Muslims did not use mechanics in any utilitarian applications and that its use was limited only to entertain the kings and caliphs.

4-Water fountains were not just an extravagance or luxury, but rather they were an exquisite part of Islamic gardens with a practical function, symbolic significance and aesthetic value. 


\section{References:}

1- Donald Rehail, Science and Engineering in Islamic Civilization: Basic Blocks in the Edifice of Human Civilization, translated by Ahmed Fouad Pasha, The World of Knowledge, Issue 200, July 2004.

2- Ragheb Al-Sirgany (d), Fountains in Islamic Gardens

3- Sabih Sadiq, Official Opening of the Water Flow from the Sabaa Fountain in the Alhambra Palace, Al-Sharq Al-Awsat Newspaper, Issue 19109, dated January 16, 2018.

4- Mohamed A. Suleiman, Muhammad S. Al-Rashidi, Hani G. Mohamed, Building of International Company of the Suez Canal Marine, Port Said City (Architectural Innovation Design of $19^{\text {th }}$ Century), International Journal of Architectural Engineering and Urban Research, Vol. 1, No. 1, 2018, pp. 13-19.

5- Nagwa Mohammed Ismail Eltawab, Innovation Of The Employment Of Heritage Character In Islamic Architecture, International Journal of Architectural Engineering and Urban Research, Vol. 2, No. 1, 2019, pp. 1-9.

6- Abeer Ali, Fountains through the ages from the utilitarian function of moisturizing the atmosphere to the aesthetic purpose, Dunia Al Watan, dated November 1, 2010.

7- http://pulpit.alwatanvoice.com/content/print/213165.html

8- Hisham Muhammad Abdel Azim Al-Marsfawi, Mechanical Arts for Arab Muslims in the Period from the Third to the Seventh Century Hijri, Master Thesis, College of Applied Arts, Helwan University, 1999.

9- Emma Clark, The Art of The Islamic Garden, Crowood Press, 27 July Y..0. http://theislamicmonthly.com/the-art-of-the-islamic-garden/ http://www.thefreedictionary.com/fountain

10- http://www.dictionay.com/browse/fountain

11- http://www.vocabulary.com/dictionary/fountain

12- https://ar.wikipedia.org/wiki\%D9\%86\%D8\%A7\%D9\%81\%D9\%88\%D8 $\% \mathrm{~B} 1 \% \mathrm{D} 8 \% \mathrm{~A} 9$

13- https://en.wikipedia.org/wiki/Will_Durant

Received: February 5, 2019

Accepted: April 2, 2019 